As Redpath Hall celebrates its 100th Anniversary the builcler of the University Organ, Hellmuth Wolff, celebrates the 25th anniversary of his firm. Mr. Wolff is of Swiss origin and he established his organ buiding business in 1968 in Laval, Quebec. The Redpath Hall organ stands at mid-point in his career and he is widely recognized today as one of the world's leading organ builders. It would be no exaggeration to say that decisions made during the Redpath Hall installation have informed all his subsequent work. But all creation begins with a vision, and as Hellmuth Wolff wrote in the inaugural programme, "The opportunity to build an organ in French classical style and the chance to install it in such a marvellous building as Redpath Hall has surely been a rewarding experience for all who have collaborated in the project. For once we have been permitted to realize a dream and we owe the realization of that dream to a benefactor without whose generosity the gallery of this hall would still be empty."

\title{
The Austin "Dink" Carroll Papers in the University Archives
}

\author{
By Robert Michel \\ Archivist, McGill University Archives
}

The papers of Austin "Dink" Carroll (1899-1991) in the University Archives document the career of one of Montreal's best known sports editors and reveal a talented author of fiction.' They include articles on sports as well as letters from hockey and baseball figures, and from readers of Carroll's columns, commenting on issues such as the riot that followed the suspension of Montreal Canadiens hockey player Maurice Richard in 1955. Most important, the papers also contain unpublished short stories and novel fragments as well as letters from Carroll's close friend, writer Morley Callaghan (1903-1990). What follows will offer a glimpse of Carroll's literary side.

Carroll played football at McGill University, where he received his law degree in 1923. He never practised law; instead he made sports and writing his vocation. He was a travelling road secretary for the Toronto Maple Leafs of the International Baseball League, worked in advertising for the Canadian Pacific Railway, and wrote freelance before establishing himself as a sports journalist at the Montreal Gazette from 1941 unt1l 1987. ${ }^{2}$ He boxed, flyfished, and golfed and wrote on these sports as well as on hockey, football and baseball. Other reporters admired Carroll for his literacy, honesty, refusal to accept gifts from team promoters, and tactful omission from his column of things blurted out by athletes drinking too long into the night in Montreal bars. ${ }^{3}$ According to Peggy Carroll, her husband never took notes, relying wholly on his memory. This encouraged the athletes and managers he interviewed to speak freely. Carroll would track down some of the players he wanted to interview with the help of tipsters. Other athletes would drop into his Gazette office - among them was Maxie Berger, a leading Montreal boxer in the 1940s and 1950s. Once they were talking about books and Carroll asked what he'd read lately. Berger replied: "No novels but I have been dipping into Spinoza". ${ }^{4}$

While other sports writers may have dreamed of being athletes, Carroll probably dreamed of being a novelist like his friends Morley Callaghan, Hugh McLennan and Mordecai Richler (Figure 1). At ninety Carroll advised young journalists: "Use simple words. But use them in a fresh way - the way Churchill did. "5 His Gazette columns and his stories show he followed his rule. McLennan told his McGill classes to read Carroll's column for prose style, ${ }^{6}$ while Callaghan gave stories to Carroll for comment before sending them to the publisher. ${ }^{7}$

The Carroll Papers include about thirty letters from Callaghan to Dink and Margaret Carroll from the 1930s to the 1980s, with news about friends and writing projects, comments on sports, and occasional gossip about writers. Writing to Carroll in December 1935 from New York, Callaghan related the story of a fight a year or two earlier between Ernest Hemmingway and his ex-publisher Robert McAlmon. Callaghan seems to have picked up McAlmon's version after running into him in New York. Callaghan wrote: 


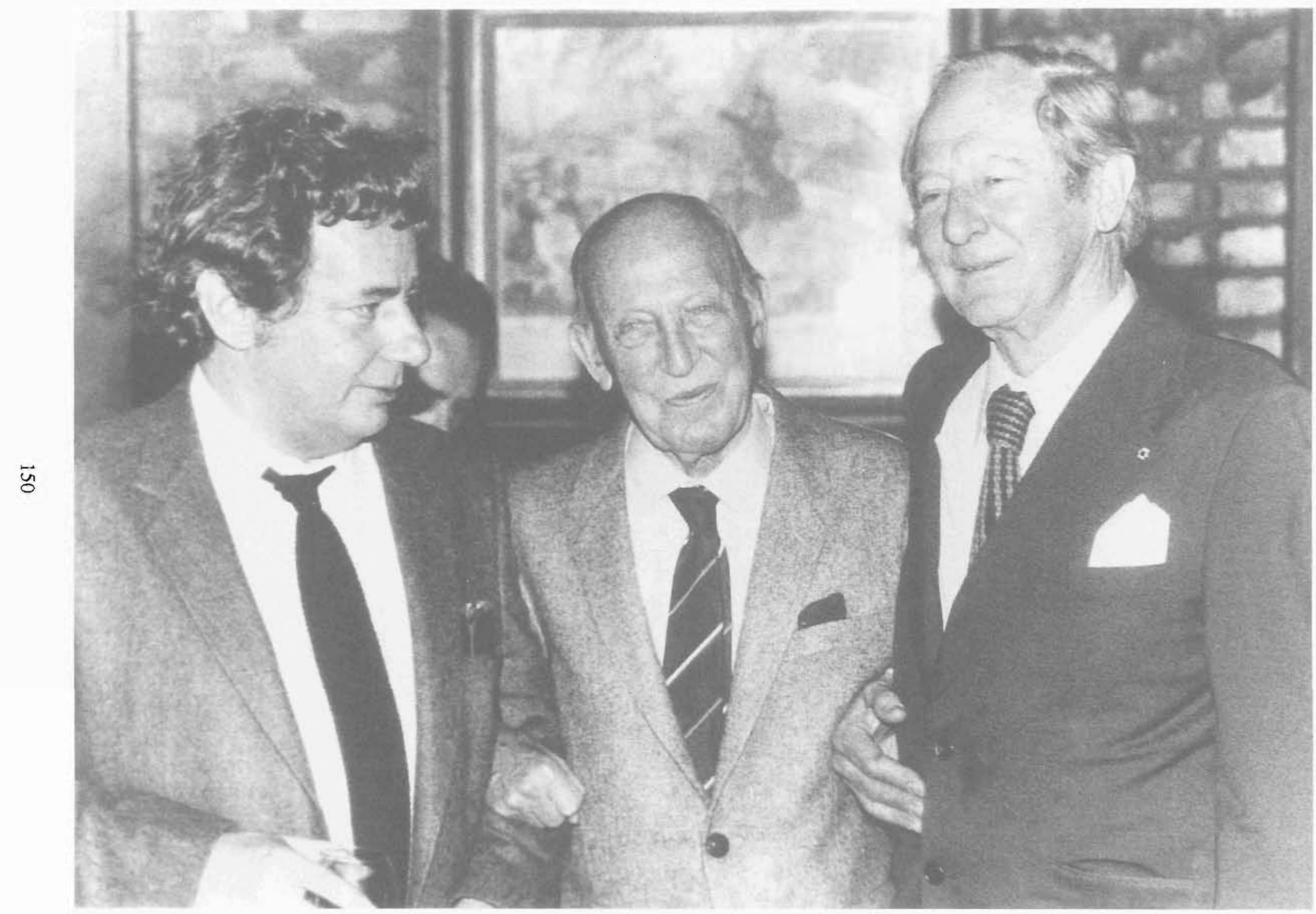

Figure 1. Carroll with Mordecai Richler and Hugh MacLennan at his $80^{\text {th }}$ (realiy $81^{\text {st }}$ ) birthday party. (Photograph: George Cree, Montreal Gazette, 15 November 1980.) 


\section{Nores and Comments}

I've seen Bob McAlmon a couple of time[s]. Do you remember me speaking of him a lot? We knew him in Paris and he first published Hemingway and has written enough books himself to cover the wall of heaven, but they won't publish them. Do you remember the guy I mean? Well, he's written the story of his wanderings and the grand old days in Paris with too intimate and too personall opinions about every body, including the Scandinavian Callaghan. It seems that when Hemingway was on his way to Africa, about two years or a year and a half ago, he ran into McAlmon, his old pal, and ups to him and says ["] I hear you've written a book and said some lousy things about me and my wife, Well, anybody knows you're trying to get a little cheap publicity". Them was hard words from an old crony, so McAlmon ups $[$ [o] him and says "You should talk about me trying to get publicity out of you. You who have used your wife and child and God knows what else for publicity". So Hemingway smacks him. He falls back against the wall and a couple of guys part them and are talking and Hemingway says, "You've always been telling dirty stories about me. You told them to Callaghan and Fitzgerald". The next step I can't get clear. But McAlmon says he said something about my stories being better than Hem's and Hemingway said of my aforementioned stories, "That Chicken shit" and suddenly reached over and smacked Macalmon a whopper on the mouth cutting the mouth so badly it required stitches. The mark is still on the lip.

Now that story is all right, and I'm willing to believe Mr. Hemingway alluded to my masterpieces as chicken shit, but I don't think he hit him out of professional envy of my work. It just doesn't ring true. He hit him because of the stories Bob had been telling.

Still my candid opinion is that it was pretty lousy of uncle ernest to smack him, when McAlmon had no luck and had helped Hemingway in the beginning. ${ }^{8}$

McAlmon had helped Hemingway publish and become famous. Stories about this falling out vary. Callaghan"s letter to Carroll adds to the canon of stories about this famous quarrel between writers, which began with creative insults and ended illiterately with blows. ${ }^{9}$

For many writers of the 1920s and 1930s writing and sports went together; good writing resembled athletic prowess; writers and athletes both conquered obstacles and proved their skills. Sports such as bull-fighting or football provided a ready made arena for suspense and heroism. Callaghan's letter about the Hemingway-McAlmon fight went on to describe a football game between the New York Giants and the Chicago Cardinals, probably that played on 27 October $1935 . .^{10}$ Callaghan enclosed a diagram of the spectacular play he described (Figure 2):

I saw a funny and very pretty pass in the pro game which may not have been deliberate, but certainly looked as if it was. The half takes the ball and starts to fade to the left to pass, they come in on him and he starts to run even further to the left taking up more time, and everybody sees that he intends to pass the ball way down the left, not only because he's going to that side but because the receivers by this time are all grouped way down on the left waiting for the ball to turn up. Then when the passer is way over to the left he suddenly passes at a diagonal across the field way over to the right, where there is absolutely no one, but just as he starts to pass, the end who has been badly covered down on the left side suddenly shoots out heading fo[r] the right side as if someone had told him his grandmother was dying over there, and he takes the ball on the dead run, absolutely uncovered. It sounds simple but it certainly looked swell, I'll enclose a diagram. Maybe it was just an accident and would never happen again, but that Cardinal team could sure pass the ball. ${ }^{11}$

The Carrolls and the Callaghans visited and wrote back and forth between Montreal and Toronto for fifty years. 


\section{Notes and Comment:}

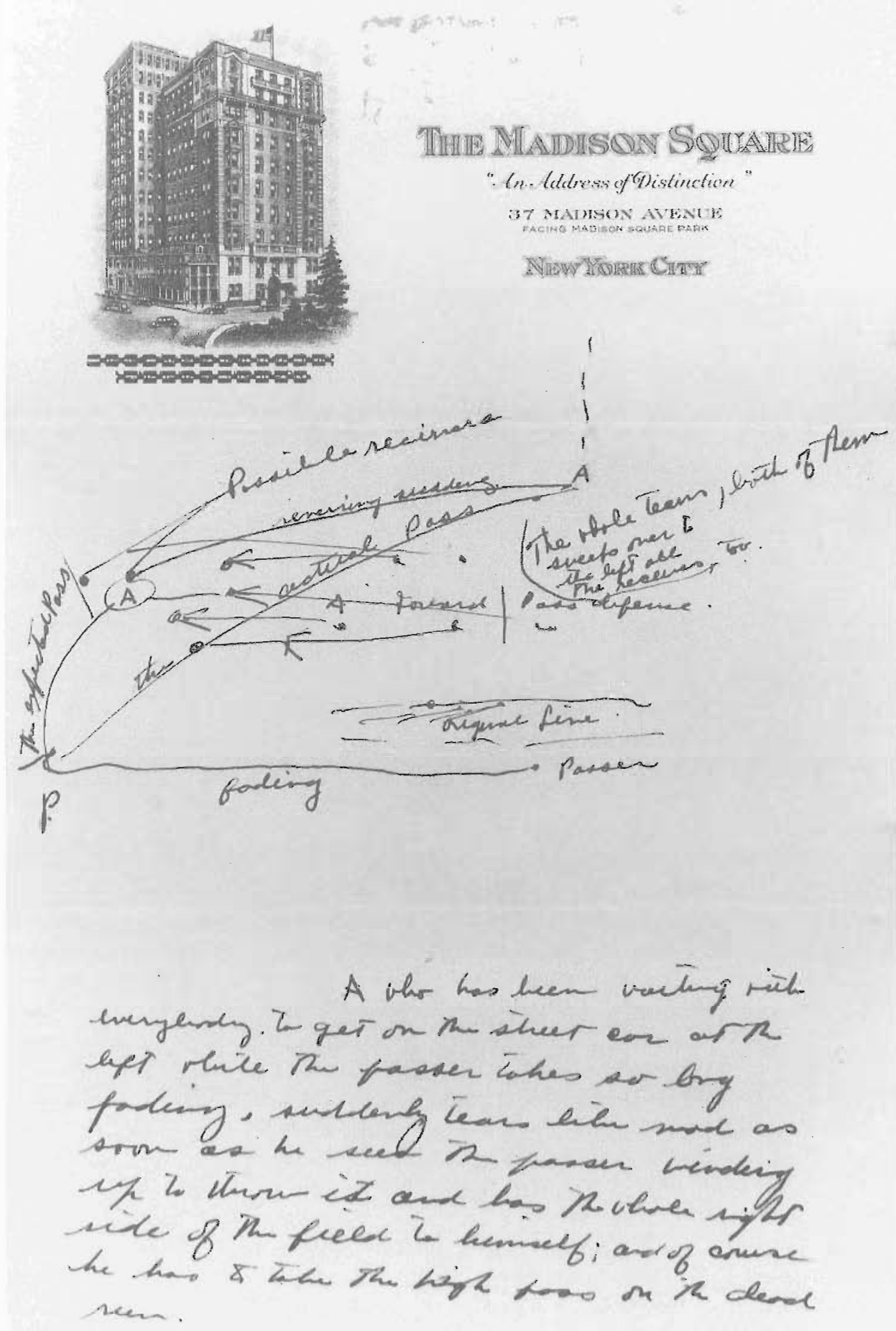

Figure 2. Morley Callaghan to "Dink" Carroll, ca. 2 December 1935. The diagram probably refers to the New York Giants and Chicago Cardinals football game of 27 October 1935. 


\section{Notes and Comments}

In 1949 Mrs. Loretto Callaghan typed a note from Toronto to Margaret Carroll, referring to one of the hazards of being married to a writer:

"Life right now is just the same old round. Morley has gone down to the C.B.C. to do his program. When I asked him where the typewriter was, I wanted to use it, he thought I was going to do some typing for him. He has been working on his Montreal book and has been trying to interest me in typing it. I told him I was completely out of practice, as you can see, and that anyway I didn't like typing. ${ }^{12}$

Callaghan's example must have helped inspire Carroll to write fiction. In what may be an autobiographical reflection, Carroll speaks through one of his fictional characters, a Montreal advertising man and would-be novelist:

What I really should have done instead of becoming a copywriter was to have written a novel based on undergraduate life. This I should have done the first year I was out of college, like F. Scott Fitzgerald. Then I could have had my picture in the rotogravure sections of the Sunday papers and gone to live in a Hollywood Hotel, or a Paris flat, or maybe in a pent house in New York. That is what I should have done all right. Now it is ton late, I have been out of college too long. ${ }^{13}$

Carroll started a novel on his life at McGill; he also wrote at least twenty short stories (probably from the 1930 s to the 1950s) and part of an autobiographical novel set in advertising. ${ }^{14} \mathrm{He}$ always wrote about what he knew sports, student life at McGill, Montreal nightlife, romance, and the perils of the business world. His story titles include: "The Second Year Jinx", "The White-haired Boy", "Supreme Sport Judge", and "The Old Lady Moves". Carroll's style is always clear, hard-boiled, often humorous. While most of the stories were never published, one, "The Amateur", narrated by the manager of a professional hockey team, appeared in Esquire in January 1936. Here is part of an unpublished narrative told by a rookie hockey player in the Intemational League, in a story set in 1.907:

We were winning the game, 3-1, and I had scored two of the goals, and I couldn't resist making grandstand play. I wasn't hurt and I could have gotten up alright, but I aliowed the other players to carry me to the bench. The applause of the crowd was music in my ears. Our trainer was John Hammond, an old handler of fighters, and he knew only two ways to treat a tired or injured athlete: one was to give him a whiff of the ammonia hottle, and the other was to give him a shot of brandy.

"Here, kid, drink this!" he said, and he handed me a bottle.

I took a gulp from the bottle and then I really was in agony. Old John had handed me the wron: bottle and the spirits of ammonia had set fire to the inside of my mouth. They lugged me off to a doctor, who put me [on] a strict diet of cream for the next 10 days. That cured me for all time of playing to the grandstand. ${ }^{15}$

Other stories and sketches were drawn from Carroll's early stints in the business world. Among his sketches for the advertising man novel (set in the 1930s), he describes an office party:

The annual office party is an event I look forward to because something always happens to make it memorable. People you have been working alongside day in, day out for a year or more have a habit of stepping out of their characters at this kind of frolic. 


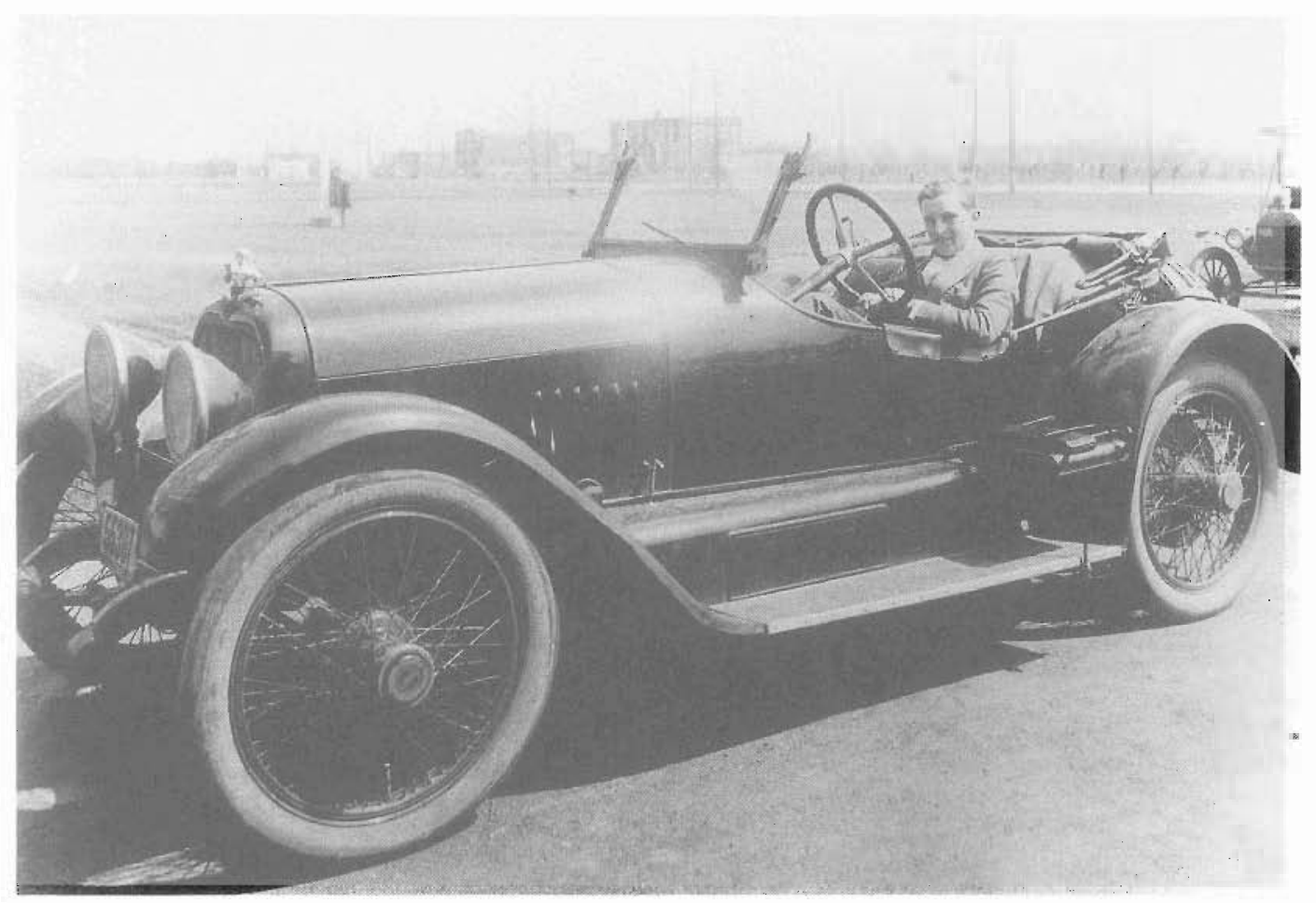

Figure 3. Carroll in sports car, 1920s.

Many firms make their annual get-together a summer picnic. Then they do not have to pay for the damage. A forest fire or a drowning come cheap. It is something else, though, when an hotel sends in a bill of damages... Our party always takes the form of a dinner dance at one of the hotels. True, the hotel may be somewhat obscure, but anyone who would object to that is a little too choosy. ${ }^{16}$

After this gentle introduction, the story takes wing. A friend of the narrator hopes to make a good impression on a secretary, Miss Holiday, but gets very drunk before the office party begins. Wondering if he can make himself presentable, he realizes he "must have a breath like a swordfish". Smiling at a mirror, he realizes something worse: he has lost his false teeth down a drain. He suspects the good impression on Miss Holiday will not be made.

Like many writers between the two world wars, Carroll explored the themes of money and social mobility, the business of writing, sports, emancipated women, and changing sexual mores (Figure 3). He grafted the themes explored by Fitzgerald and Hemingway on to simply, deftly portrayed Montreal settings. His characters reflect the attitudes of their times. Writing in the 1930 s (probably), he described Joe, recently graduated from McGill, thinking about his girlfriend (the time is the late 1920s):

Many girls, he [Joe] knew from his own experience, could not be trusted out of sight. But with Kay he knew where he stood and so did everybody else. When they went with a crowd on a party, to a night club or to the country over a weekend, there was never any doubt about whose girl she was. The chisellers soon saw it was no use, that she was a square-shooter, and passed 
on to continue the search elsewhere. It gave Joe such a feeling of confidence that he thought more than once if he were in a position to marry he had found the right girl.... Whenever he thought of her, he saw her first always in sports clothes; a slender blonde girl who would be willowy if she were taller, driving a golf ball a surprising distance, swimming better than most men, no dead weight in a dinghy, dancing tirelessly, knowing when to stop drinking, as agreeable as a man but with the other interest always there. ${ }^{17}$

Kay is a moderate Canadian version of the New Woman - free, unconventional, athletic, tomboyish or masculine, who fascinated many writers of the 1920s and 1930s, and was personified by such heroines as Hemingway's Brett Ashley in The Sun Also Rises. ${ }^{18}$

While Carroll's published sports journalism is preserved in the Gazette and other periodicals, his unpublished fiction and letters from Callaghan in the Archives are an important literary legacy. The stories tell of football games and pocket flasks, roadsters and fraternities, emancipated women, office hi-jinks, and legends of prowess on the sports field and in the bar room. Carroll's papers offer readers interesting stories, lively correspondence, and memories of Montreal when it was the unchallenged Canadian metropolis - the gleanings of a long and well-enjoyed life.

\section{Notes}

A. McGill University Archives. Austin "Dink" Carroll Papers, MG 4151, originals, ca. 1920-1991, one linear metre. The bulk of the papers are incoming correspondence and writings by Carroll; there are also photographs, taped radio interviews, autographed programmes and other memorabilia. The papers were donated by Carroll's wife Margaret (Peggy) Carroll, who worked as a reference librarian in the Redpath and McLennan Libraries and later at the McCord Museum.

2. He published in The Montrealer, Esquire, Saturday Evening Post, Collier's, The Reader's Digest, Liberty, and the Toronto Star Weekly.

3. Carroll's supposed 80th birthday - he really was 81 - occasioned a large party and several articles in the press providing some biographical information used here: see David Sherman, Montreal Gazette (15 Nov. 1980); Tim Burke, Montreal Gazette (7 Nov. 1980); Paul Rimstead, Toronto Sun (10 Nov. 1980). According to Sherman, Carroll was nicknamed "Dink" as a child, when he could not pronounce Rs and would ask for a "dink" of water.

4. Letter, Margaret Carroll to Robert Michel, 3 July 1991 in Archives accession file 91-028.

5. Bob Morrissey "Carroll is never far from the words that have been his life", Montrealers column, Montreal Gazette, 12 Nov. 1989.

6. Sherman, Montreal Gazette (10 Nov. 1980).

7. Letter, Margaret Carroll to Robert Michel, 3 July 1991 in Archives accession file 91-028.

8. Letter, Morley Callaghan to Dink Carroll, undated (accompanying envelope postmarked 2 Dec. 1935), MG 4151, c. 4, file: "Letters from Morley Callaghan".

9. Callaghan's That Summer in Paris (New York 1964), pp 76-78 gives McAlmon credit for using his money to publish writers he believed in. The fight is mentioned in several biographical works. Robert McAlmon and Kay Boyle, Being Geniuses Together 1920-1930 (New York 1968), p.352, notes that at the time "Hemingway weighed over two hundred pounds... and Bob about a hundred and fifteen soaking wet." Denis Brian, The True Gen (New 
York 1988), p. 194 reports that they exchanged charges of homosexuality and mistreatment of wives. According to Kenneth S. Lynn, Hemingway (New York 1987), p.417, Hemingway heard McAlmond planned to write unpleasant things about him in his reminiscences (returning Hemingway's uncomplimentary portrayal of McAlmond in Death in the Afternoon) and beat him up without waiting for confirmation or denial.

10. The match took place on Sunday, 27 Oct. 1935 in New York before a crowd of 32,000 including the Postmaster-General James Farley. The New York Times, 28 Oct. 1935 and 3 Nov. 1935 reports the game, noting that Chicago had won the game from behind (14-13) through a strong running attack and a wide-spread passing formation, particularly a forward pass from Ike Peterson to Bill Smith which gained 46 yards and a touchdown. Perhaps, that was the play Callaghan meant but the columnists do not mention the strategy in Callaghan's terms.

11. Letter, Morley Callaghan to Dink Carroll, undated (accompanying envelope postmarked 2 Dec. 1935), MG 4151, c.4, file: "Letters from Morley Callaghan".

12. Letter, Loretto Callaghan to Margaret Carroll, 18 March 1949, MG 4151, c.4, File: "Letters from L. Callaghan". The Montreal novel was The Loved and the Lost (1951).

13. MG 4151, c.1, untitled.

14. Archives MATCH Volunteer Elizabeth Shapiro, who helped arrange and describe the Carroll Papers, undertook the daunting task of identifying and piecing together the often-disordered works of fiction.

15. MG $4151, \mathrm{c}, 1$, untitled story.

16. MG 4151, c. 1 , file 4 : drafts for an untitled novel(?)

17. MG 4151, c. 1, untitled.

18. Ernest Hemingway, The Sun Also Rises (1926), chapter 3: "Brett was damned good looking. She wore a slipover jersey sweater and a tweed skirt, and her hair was brushed back like a boy's. She started all that."

\title{
History of the Polish Institute Library in Montreal
}

\author{
By Hanna M. Pappius, Ph.D. \\ Director of the Library, Polish Institute
}

In 1943 a group of Polish academics who had found refuge in Montreal, together with a number of their Canadian colleagues and with the enthusiastic support of the eminent Polish historian Professor Oskar Halencki, then at Columbia University, established the Canadian Section of the Polish Institute of Arts and Sciences in America. One of the first decisions of the new section was to start a library. Subsequently, the Canadian Section became the Polish Institute of Arts and Sciences in Canada (PIASC). As PIASC approaches its 50th anniversary the Polish Library at McGill University can be considered as its most important and enduring achievement.

In 1943 the library consisted of a small collection of books for the use of members of PIASC. By the end of World War II its character had changed with a readership extending to the whole Polish community in Montreal and beyond, although it continued to be run exclusively by volunteers. It was only in 1982 that PIASC obtained a grant from the City of Montreal for the services of a professional librarian. This was a crucial development for the Polish Library as its operation without professional staff was begining to seriously impair its growth. In the last decade the Polish Library has steadily increased its holdings and its activities. 